\title{
Kuwamai: Historic Epidemics and Resilience of Cariban-Speaking Peoples, Northern Amazonia
}

\author{
Renzo S. Duin \\ (D) https://orcid.org/0000-0002-0525-2667
}

International Center for Amazonian Indigenous Knowledge (AMIK), Netherlands Department of Anthropology, University of Florida, USA

\begin{abstract}
How Amazonian Indigenous Peoples combatted emergent epidemic diseases in colonial times, and their innovative responses to epidemiological crises, has not received sufficient attention. This study outlines a clash of cultures and an entanglement of places and people related to pandemic diseases and epidemic death in the Eastern Guiana Highlands, northern Amazonia. By means of archival and historical sources, the article provides eyewitness insight into multiple waves of highly contagious epidemics that affected Cariban-speaking communities in Eastern Guiana - Suriname, French Guiana, and Brazilian Amapá - over the past 550 years. The paper commences with some general statements on illness and healing. Hitherto unpublished journal entries by the Governor of Suriname of an outbreak of the pox during the winter of 1743-1744 set the scene, these are followed by rare nineteenth and twentieth century historical accounts, and a novel interpretation of Wayana oral history - posited to be the first account of the spread of a viral disease in Amazonia in July 1542. The paper concludes with responses to the current COVID-19 pandemic from an indigenous etiology which demonstrates indigenous historical consciousness of the social present as related to events from the past.
\end{abstract}

Keywords: Colonial history, Amazonian historicities, Guiana, Amazonia, Wayana, pandemic viral diseases, voluntary isolation, indigenous etiology

eTropic: electronic journal of studies in the tropics publishes new research from arts, humanities, social sciences and allied fields on the variety and interrelatedness of nature, culture, and society in the tropics. Published by James Cook University, a leading research institution on critical issues facing the world's Tropics. Free open access, Scopus Listed, Scimago Q2. Indexed in: Google Scholar, DOAJ, Crossref, Ulrich's, SHERPA/RoMEO, Pandora. ISSN 1448-2940. Creative Commons CC BY 4.0 free to download, save and reproduce. To cite, include: Author(s), Title, eTropic, volume, issue, year, pages and DOI: http://dx.doi.org/10.25120/etropic.20.1.2021.3759 
eTropic 20.1 (2021) Special Issue: Pandemic, Plague, Pestilence and the Tropics

\section{Prologue: COVID-19 and the Wayana}

7 he writing, editing, and finalising of this article took place during the extraordinary times of COVID-19, commonly referred to as the coronavirus. People closely follow the statistics on confirmed cases and mortality rates, and the consequent measures taken by governments attempting to cope with this pandemic. Amazonian Indigenous Peoples are not spared from COVID-19, and as I was writing this manuscript, I received notice that about 40 Wayana of the upper Maroni River, which forms the border between French Guiana and Suriname, had tested positive for COVID-19 and many more had fallen ill. During the editing process, I received notice that one Wayana man was airlifted to the hospital in Cayenne, where he passed away.

At the outset of the pandemic, in March 2020, Wayana leaders closed their airstrips for all non-medical transportation, and prevented people travelling up and downriver in order to insulate and protect their people. Nevertheless, the virus reached Wayana villages in southern French Guiana and Suriname. Social distancing measures were translated from French and Dutch into the Wayana language and distributed across Wayana villages.

Wayana and other Indigenous communities in northern Brazil were likewise not spared, as positive COVID-19 cases have been reported from the neighbouring Terra Indígena Parque de Tumucumaque in Brazil, despite measures to combat COVID-19. ${ }^{1}$ The Indigenous Peoples fear, once again, for their lives as the confirmed cases and mortality rate in Brazil and neighbouring countries continue to rise at an alarming rate.

Yet the ongoing COVID-19 pandemic is not the first epidemic faced by Indigenous Amazonian communities. The current crisis may thus also raise awareness of what Indigenous communities in an increasingly globalised world have had to go through in multiple waves of epidemia since AD 1492.

\section{Kuwamai and Indigenous Responses to Epidemiological Crises}

This article assesses how in colonial times Cariban-speaking Indigenous Peoples of Eastern Guiana combatted emergent epidemic diseases. It reveals their innovative responses to epidemiological crises related to epidemic viral diseases with flu-like

\footnotetext{
${ }^{1}$ For example (websites accessed on August 1, 2020):

- https://www.diariodoamapa.com.br/cadernos/geral/missao-tiriyo-governo-do-amapa-integra-acao-decombate-a-covid-19-no-parque-indigena-tumucumaque/;

- https://www.folhape.com.br/noticias/militares-levam-covid-19-a-terra-indigena-remota-da-amazonia-afirmamI/143140/;

- http://www.mpf.mp.br/pgr/noticias-pgr/mpf-recomenda-ao-governo-federal-providencias-para-combate-acovid-19-na-terra-indigena-parque-do-tumucumaque.
} 
eTropic 20.1 (2021) Special Issue: Pandemic, Plague, Pestilence and the Tropics

symptoms, and focuses on what the Wayana people call "kuwamai", a specific kind of tïlëkhem (epidemic).

The Wayana reside in the upper regions of the northern Brazilian states of Amapa and Pará, southeast Suriname, and southwest French Guiana (Figure 1). One of the main ethnic units within the Wayana confederation are the Upului who originate from the Jari Valley along a northern tributary of the Amazon River. The Wayana and Upului languages belong to the Cariban language family, as does the language of the Caribs (Kalinya) who reside along the coast and coastal uplands of the Guianas - Guyana, Suriname and French Guiana.

The cosmology, epistemology and etiology of the various indigenous Cariban and Arawakan-speaking communities in Eastern Guiana is akin, particularly in how they relate to sickness and healing. From an indigenous perspective, a supernatural malevolent entity brings disease, nevertheless, there are great variations in remedies and in the execution of the healing process (Ahlbrinck, 1931; de Goeje, 1941, 1942, 1943, 1949; Penard, 1928; Roth, 1915). "Indigenous Peoples are aware that epidemic disease such as kinderpokjes [literally "children pox" - most likely smallpox, possibly chickenpox ${ }^{2}$ (Janssens, 1981)], malaria-fever, dysentery, etc. are imported by white people and they assume that their own physicians are powerless against these diseases" (van Panhuys, 1936, p. 53; translation by the author). Other than this general statement, and as far as I am aware, no in-depth study was made of the indigenous etiology regarding these epidemic diseases in Eastern Guiana.

The present article discusses how these Cariban-speaking Amazonian Indigenous People responded to one of the most impactful processes in colonial history when Europeans - and the enslaved people which Europeans brought from Africa - set foot in the Americas, bringing with them a multitude of pathogenic microbes that the original inhabitants of the Americas had never previously experienced. This article is centred upon the indigenous etiology or the attribution of the cause or reason of the disease referred to as "kuwamai" expressed in terms of historical and mythical explanation.

In order to understand the manner of causation of this disease, I will outline some fundamental concepts of how Cariban-speaking peoples in Guiana perceive disease and illness as these beliefs are described by missionaries and ethnographers in the early twentieth century (van Coll, 1903; Ahlbrinck, 1931; Gillin, 1936; de Goeje, 1941, 1943). Drawing on this "old data", the article contributes to "a new ethnology...and a new history of the indigenous peoples of Amazonia and nearby areas...exposing a

\footnotetext{
${ }^{2}$ For more information on smallpox and chickenpox, see the Mayo clinic (website accessed on March 3, 2021): https://www.mayoclinic.org/diseases-conditions/smallpox/symptoms-causes/syc-20353027

https://www.mayoclinic.org/diseases-conditions/chickenpox/symptoms-causes/syc-20351282
} 
eTropic 20.1 (2021) Special Issue: Pandemic, Plague, Pestilence and the Tropics

previously inconceivable dynamism to the region's societies" by means of "relating alternative histories, each with a unique perspective and voice" (Fausto \& Heckenberger, 2007, p. 3, 19; Hill, 2009). This complexity of European documented history and Indigenous knowledge related through myth remains largely undocumented in the Guianas (Whitehead, 2003, p. 76), and in particular, there is a lack of documentation of indigenous responses to epidemiological crises.

Figure 1. Map of the Eastern Guianas indicating the location of peoples and places

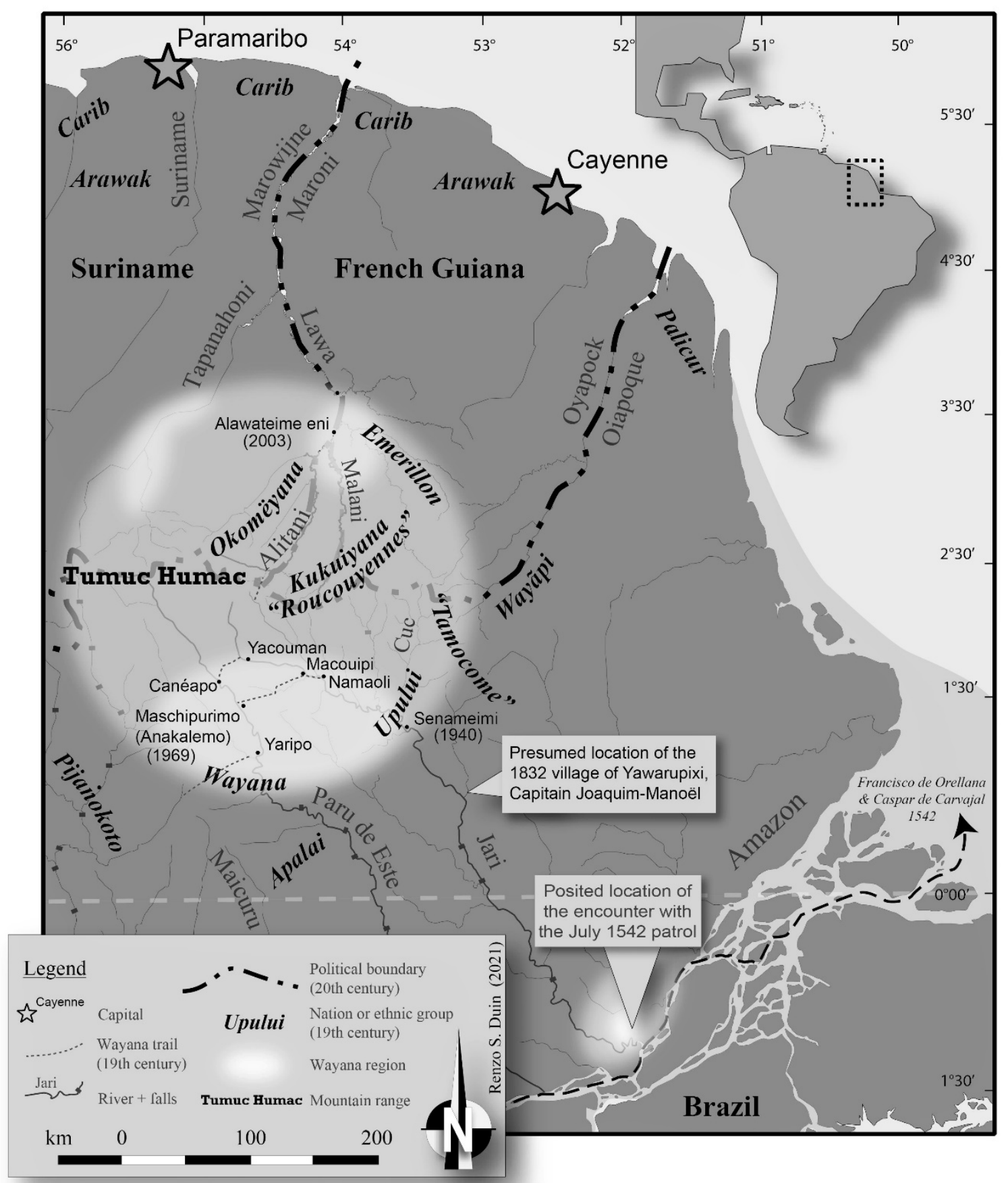

Map location of peoples and places mentioned in this article. Source: author. 
eTropic 20.1 (2021) Special Issue: Pandemic, Plague, Pestilence and the Tropics

This multi-disciplinary analysis of archival documents, historical sources, and Wayana oral history, provides insight into indigenous historical consciousness and historicity pertaining to epidemic viral diseases. The devastating impact of the clash of cultures between Amazonian Indigenous Peoples and Western "civilization" has been well established, including the impact of European introduced diseases on indigenous populations of Guiana (Albert \& Ramos, 2000; Hemming, 1978; Hurault, 1963, 1972). Likewise, ethno-historical insight into the multitude of communities ('tribes') in the Eastern Guiana Highlands, and the historical migrations of these communities, has been documented, and I refer to the ethno-historical studies conducted by Peter Rivière (1963), Jean-Marcel Hurault (1972), Pierre Grenand (1972) and Dominique Tilkin-Gallois (1986, 2005). These rich collections of historical documents are written in Dutch, French, German, English, Portuguese and Spanish, which has often resulted in an incomplete reading, or the exclusion of documents written in languages other than those of the researcher, let alone an indigenous perspective in the Wayana language or other indigenous languages. This paper offers a more inclusive discussion by incorporating colonial documentation from these European languages as well as Indigenous language documentation.

In what follows I first outline the indigenous etiology of "kuwamai" before moving on to discuss this notion of epidemia within historical case studies. Entries from the journal of the Governor of Suriname on a highly contagious epidemic outbreak of the pox in the fall and winter of 1743-1744 sets the scene; it is followed by translations of the documentation of an outbreak of the "coughing disease" carried out by a Maroon ethnographer, this situation is further put into context through translations of rare Dutch and French historical accounts pertaining to epidemics and the demographic decline of Indigenous Peoples of the Eastern Guiana Highlands; I then show how Wayana oral history regarding a ritual dance reveals a longer history of indigenous awareness and fear of epidemics - and the fear of the return of the 'malevolent entity' Tamok; finally, we return to the social present. The ongoing COVID-19 pandemic may raise awareness of the affects and self-imposed measures of social distancing which Amazonian Indigenous Peoples have practiced in the past and maintain today, and the stress put on successive generations of Indigenous Peoples who have lived through long-term measures of social distancing and self-imposed social isolation.

\section{Concepts of 'Illness' among Wayana and other Cariban-speakers}

Before proceeding, let me briefly outline some general concepts of sickness and health among the Cariban-speaking peoples of Guiana. In the Wayana language, the state of being sick is expressed in terms of being "not healthy" - wamela wai: uwame means healthy, with the negation suffix -la and wai I am. In general, it is believed that sickness and death is brought upon a person due to the interference of a supernatural 
eTropic 20.1 (2021) Special Issue: Pandemic, Plague, Pestilence and the Tropics

malevolent entity (yoroka, Carib ${ }^{3}$; jolok, Wayana ${ }^{4}$ ) which can only be healed by means of the intervention of a piai-man (püyéi, Carib; pijai or pijasi, Wayana) (van Coll, 1903, pp. 523-528; Ahlbrinck, 1931, pp. 43, 399, 533; Gillin, 1936, pp. 176-180; Penard 1928; Chapuis, 2015; for a comparison with the Arawak in Guyana see: de Goeje, 1942). I use the Cariban term piai over the more popular shaman. The term 'shaman' is of Siberian origin, coming into use after the term piai - peeai, payé or paygi - had been introduced to Europe in the 1550's (Harris, 1926, p. 92 [Harcourt, 1613]; Staden, 2008 [1557], p. 124). As analysed by John Gillin (1936, p. 179), "the first task of the consultant [the pial] is to determine which spirits [malevolent entities] are causing the trouble" - which is evidenced by fever (atu, Carib; tijephe, Wayana).

Rather than perceiving illness - "not being healthy" - as an isolated physical phenomenon, the piai often treats illness within the context of tensions and anxieties of intra- and interfamilial social relations. Healing of an individual is thus more than merely a corporeal cure of the physical being. Penard (1928) provides a description of the training of the piai (see also: de Goeje 1942). Some piai may be involved in dark practices, such as assault sorcery and witchcraft known as kanaima (Whitehead \& Wright, 2004), or they may simply be accused of shooting "spirit stones" or other implements - bird beaks, glass, etc. - into a person's body. The Wayana call these small malicious "arrows" jolok pïle (de Goeje, 1941, pp. 95-96). Consequently, many pains and ills are attributed to such attacks by a piai (Gillin, 1936, p. 173). Tobacco smoke from a long cigarette is the key implement of the piai for communicating with the ancestors and the malevolent entities (see Duin, 2015).

In order to restore the healthiness of a person, in the evening - preferably during a moonless night - and within the dark of a specially erected enclosure, or "consultation room" made from palm fronds (tokai, Carib; tokai, Wayana), the piai will meditate between the ailing, the deceased, the living, and the malevolent entities. Upon request, I have participated several times in such tijumkai-sessions ${ }^{5}$ performed by a Wayana pijai in search of the culprit responsible for the illness.

A special category of illness is what the Wayana call kuwamai or kuwamasi, ${ }^{6}$ typically identified as the epidemic common cold, sometimes developing into pneumonia (de Goeje, 1941, p. 95), consistent with flu-like symptoms or catarrh, i.e., the acute or chronic inflammation of a mucous membrane, especially in the upper airways (nose, pharynx), with non-purulent hypersecretion of its glands (Camargo \& Tapinkili, 2010,

\footnotetext{
${ }^{3}$ Spelling according to Ahlbrinck, 1931.

${ }^{4}$ Spelling according to Camargo and Tapinkili, 2010.

5 tijumkai to invoke the 'master': tïkai:1. to say, 2. to do. jum: 1. father; 2. master, origin (compare with the concept of the "Mothers" among the Yagua in Nord-East Peru as discussed by Jean-Pierre Chaumeil, 1983).

${ }^{6}$ Alternatively spelled as couamaye (Crevaux, 1881; Coudreau, 1893, p. 543), kuamai (de Goeje, 1941, p. 95) or kwamai (de Goeje, 1949).
} 
eTropic 20.1 (2021) Special Issue: Pandemic, Plague, Pestilence and the Tropics

p.81). Wayana distinguish kuwamai from a regular fever (tijephe). As discussed in more detail below, European explorers visiting the Wayana villages at the turn of the twentieth century recurrently describe the occurrence of this epidemic illness with symptomatic fever, running nose and headache - a flu-like illness which cannot be cured by the local piai (pijjai). Even today, Wayana fear catching a common cold.

These illnesses brought by Europeans that are incurable by the piai are often linked with shortness of breath (dyspnea; pëlëmnë, Wayana). This is addressed in the account by Kulijaman, an Apalai originating from the Paru d'Este who concludes: "tïlëkheme sike tïlëmëphë lëken" which Aimawale translated into French as "on ne peut que mourir parce que c'est une épidémie" [We can only die because it's an epidemic] (Chapuis \& Rivière, 2003, pp. 854-855 [translation to English by the author]).

Tilëkhem is being translated by both Aimawale and Takwali as "epidemic", yet Camargo and Tapinkili (2010, p. 83) translate this term more generally as "sentir la douleur, avoir mal" [feeling pain, having pain], illustrated with the examples: "ïwane wilëkjai" [I have pain in my heart] and "iwetepu wilëkjai" [I have pain in my stomach] from the root -lëk. This root should not be confused with the noun ëlek (wound, sore) or the root -elïk (killing, attacking). It may be related to tïlëmëphe [to die]. For instance, after a hard day's work one can express tïlëmahpoi [l am dead tired!].

Neither Camargo and Tapinkili (2010), nor other linguists (pers. comm. Sérgio Meira, 2021), can provide further insight into the etymology of the term kuwamai or kuwamasi. An investigation of the etymology of the concepts of tilëkhem and kuwamai may provide more insight into the indigenous etiology, but is beyond the focus of this article. Of significance for this paper is how the Wayana and their ancestors have combatted emergent epidemic diseases - with kuwamai symptoms - since their introduction during colonial times.

\section{Pox Outbreak in the Winter of 1743-1744 (Paramaribo, Suriname)}

To set the scene to one of the most devastating processes in colonial history - that of Europeans bringing with them to the Americas a multitude of pathogenic microbes that the Indigenous inhabitants had never previously experienced - I present hitherto unpublished journal entries by the Governor of Suriname. ${ }^{7}$ During the winter of 17431744 , the Governor of this Dutch colony noted in detail an outbreak of kinderpokken ("children pox"; most likely smallpox, possibly chickenpox). The following incidents occurred in Paramaribo, the capital of Suriname.

\footnotetext{
${ }^{7}$ Nationaal Archief, Den Haag, Sociëteit van Suriname, nummer toegang 1.05.03, inventarisnummer 199, folios 330 till 510. All transcriptions and translations from Dutch to English are by the author.
} 
eTropic 20.1 (2021) Special Issue: Pandemic, Plague, Pestilence and the Tropics

On Sunday October 20, 1743, doctor Kiellman, "who was loved by everyone, possessing a fair mind, and a profound knowledge of his art, with the least of Charlatanry" (author's translation), ${ }^{8}$ passed away and was buried the next day. In the following months, the Governor of Suriname dedicated several entries in his journal to the people fallen ill of this disease. Several high officials such as the Lord Commander, the Lord Fiscal, the Sales Master, the Director of the Mining Company, the Jewish Captain David Cohen Nassy, the Lutheran priest, and many others suffered from high fevers.

On Tuesday October 22, 1743, the Governor wrote that "in the house of Mr Crepij, there are 24 people - both white and black - who suffer from the pox," and although Mr Gerrit Pater has recovered, his brother, Cornelis Pater, and his brother's wife - the youngest daughter of Mr van de Schepper - are lying deadly sick. ${ }^{10}$ The latter would pass away in the night between Monday and Tuesday, November 5, 1743. The death of the wife of Cornelis Pater was very upsetting to the wife of the Governor who also suffered from strong fevers and delirium in the head. ${ }^{11}$ In his journal, the Governor specified the condition of his wife and himself almost daily, and he stated that he is surrendered to the black servants, because his white servant is ill. ${ }^{12}$ No wonder that on October 22 the Governor wrote: "one only hears of death and dying."13

Of particular interest for this paper is the following incident that occurred in the summer of 1744. On Sunday, June 21, 1744, Andries la Gord, captain of the slave ship Maria en Elisabeth - having sailed from the coast of Africa - arrived in Paramaribo. Aboard were about 360 African people to be sold at the slave auction. ${ }^{14}$ On Tuesday, June 23, the Governor of Suriname wrote an entry in his journal citing the report of the Surgeon Major which stated that some of the Africans on board suffered from "kinderpokken" smallpox - and that he therefore had called the General Court together. The Court decided to order the slave ship to return downstream, beyond the new fortress of New Amsterdam - located some 15 kilometers north of Paramaribo, facing the Atlantic Ocean - and to there remain in quarantine until further notice.

A week later, on Monday, June 29, three surgeons of the Court of Police were ordered to examine the African men, women, and children on board the slave ship. The three

\footnotetext{
8 "die van elk bemind was, besittende een net verstand, en een grondige weetenschap van sijn kunst sonder de minste Charlatanerie." (Nationaal Archief, folio 331).

9 "In 't huis van de Heer Crepij leggen 24. so blanken als swarten aan de kinderpokjes" (Nationaal Archief, folio 332). Jacques de Crepij was the owner of the sugar plantation Vreeland.

${ }^{10}$ Gerrit Pater was a member of the Council of Police and Criminal Justice, and Gerard van de Schepper was the chairman of this Council of Police and Criminal Justice and Commander over the Forts and Militia.

${ }_{11}$ In this journal, the Governor did not write down the name of his wife, nor the name of the wife of Cornelis Pater.

12 (Nationaal Archief, folio 344).

13 Entry on October 22, 1743 (Nationaal Archief, folio 332).

14 This is not the place to discuss the trans-Atlantic slave trade, on which exists a vast body of literature.
} 
eTropic 20.1 (2021) Special Issue: Pandemic, Plague, Pestilence and the Tropics

surgeons returned the next day, reporting that all had recovered and none were infected with the pox. After a general court hearing it was decided to allow the ship to sail back upstream to Paramaribo, and on Monday July 6, 1744, the slave auction was held. ${ }^{15}$

Figure 2. Journal entry (June 23, 1744) by the Governor of Suriname.

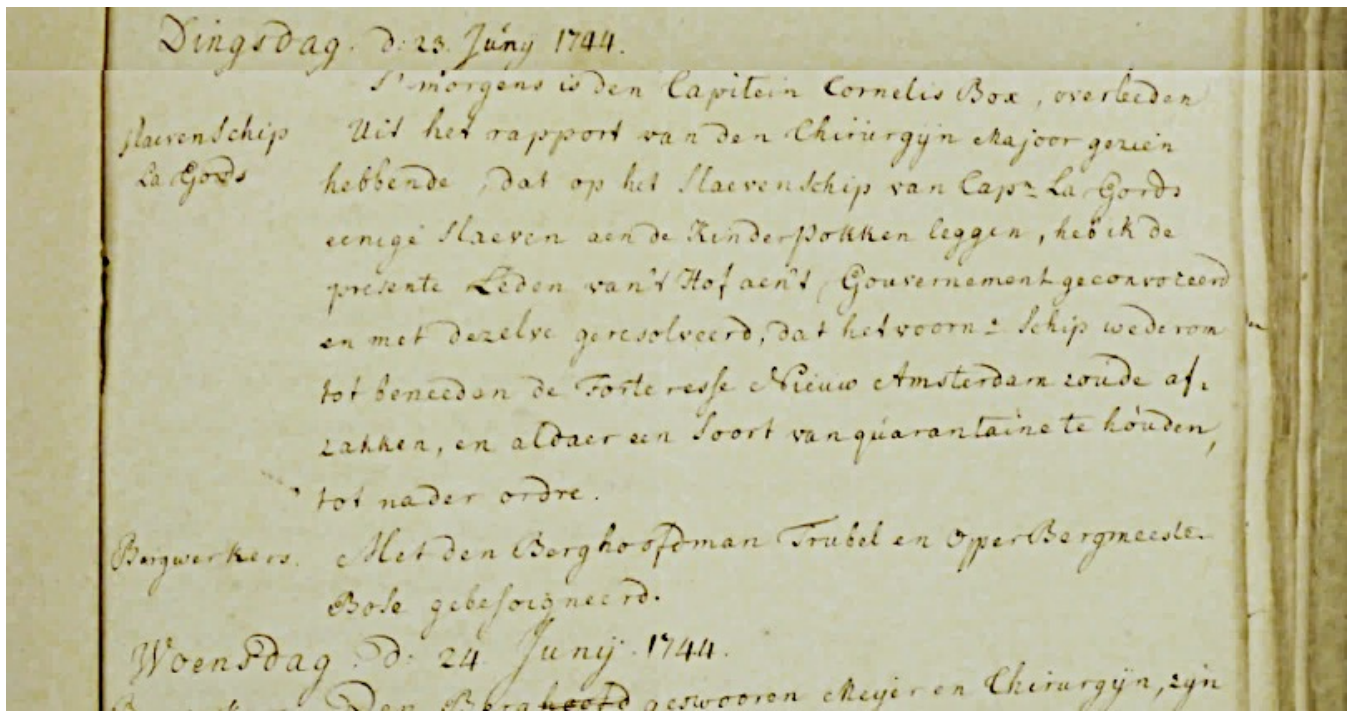

Source: Nationaal Archief, Den Haag, Sociëteit van Suriname, nr 1.05.03, inv.nr 199, folio 513.

What is of particular note in these entries - which also alert us to colonial practices of slavery and the trans-Atlantic trade in African people - is the quarantining of a slave ship which could potentially bring a highly contagious viral disease from Africa into the Americas. This enforced quarantine has to be understood within the earlier context the winter of 1743-1744, which had seen many people in Paramaribo die from the "Kinderpokjes" (literally "children pox" - most likely smallpox Variola, possibly chickenpox Varicella) as recorded in the Governor's journal.

Thus, based on the order to quarantine the slave ship Maria en Elisabeth, and the earlier recurrent entries of sickness and death, it is evident that the Governor was well aware of the epidemic spread of this highly contagious disease. Nevertheless, even while suffering symptoms of fever, he continued to preside in the Court of Police and in the Court of Justice. ${ }^{16}$ Moreover - according to other journal entries - the chairman of the Court of Police and Criminal Justice, Mr Gerard van de Schepper, and another member of this court, Mr Gerrit Pater, were also infected and potentially contagious.

\footnotetext{
${ }^{15}$ (Nationaal Archief folio 519). Archival documents in the city archive of Amsterdam state that four other slave ships arrived in Paramaribo in 1744 with respectively 340, 400, 225, and 135 African men and women on board, of which respectively $30,62,32$, and 12 passed away during the voyage. It is undetermined if these people died due to viral diseases or other causes. Neither is it specified how many people did not survive the voyage of the Maria en Elisabeth.

${ }^{16}$ (Nationaal Archief, folio 346).
} 
eTropic 20.1 (2021) Special Issue: Pandemic, Plague, Pestilence and the Tropics

On Monday November 11, 1743, Mr Polak, the Accountant of the Contribution, died of the pox, and in his journal entry the Governor specified that Mr Polak's wife, his brother, and two children had recently passed due to the very same illness; dying in the same house in which remained nine children, most of whom were also suffering from the kinderpokjes. ${ }^{17}$ The severity of this epidemic was thus well-known to the Governor of Suriname.

Moreover, this pox outbreak was not restricted to the capital Paramaribo, as is demonstrated in the journal entry of Wednesday November 13, 1743:

Tidings received from a commando of the Mountaineers of the Mining Company that the Mountain Chief Bluher, a soldier, and a slave have passed, and that most all the Mountaineers and soldiers are ill again.

For many years, the Colony of Suriname has not been in such a sad state as at present, according to the testimony of the inhabitants, one hears everywhere only of the dead and the sick. The child pox, the hot fevers, and a kind of madness, have reigned here together for some time now. Entire households are almost extinct. (NL-HaNA, Sociëteit van Suriname, 1.05.03, inv.nr. 199, folio 350; transcription and translation from Dutch to English by the author).

Nevertheless, rather than taking measures of social distancing and self-isolation, the Governor of Suriname - both himself and his wife suffering from fever and delirium in the head - requested phlebotomy, to have his let blood, in order to continue to preside in the Court of Police and Criminal Justice. ${ }^{18}$ Well into the new year of 1744 , the Governor's journal entries continue to report sickness, including of his own son, the Sales Master, and his son's wife. On January 25, the Governor wrote that he had suffered the entire week from the painful blisters that the entire country suffers. ${ }^{19}$ No social distancing measures to fight this epidemic thus seem to have been set in place - other than the quarantining of the slave ship Maria en Elisabeth, which was to occur after the deadly pox winter.

With this pox outbreak ongoing in Paramaribo, there is little to no information on how this highly contagious disease spread across the colony of Suriname. The Mountaineers of the Mining Company were active further upstream in the river Suriname and the Sara creek, and may well have infected the local Indigenous Peoples and Maroon communities residing in these areas. Moreover, several

\footnotetext{
17 (Nationaal Archief, folio 349).

18 (Nationaal Archief, folio 351).

19 (Nationaal Archief, folio 396).
} 
eTropic 20.1 (2021) Special Issue: Pandemic, Plague, Pestilence and the Tropics

commandos were sent out in search of enslaved people who had fled from the plantations. For example, in the journal entry of Sunday October 20, 1743, the Governor of Suriname specifically mentioned a commando that had been sent out to the river Saramacca, and that he well-received the Free Indigenous People who took part in this expedition, and who he further convinced to take part in a new expedition in search of the enslaved peoples who had fled from the plantations. Since the Governor of Suriname and many others of office were infected, it can be extrapolated that soldiers and citizens were likewise infected, and that Free Indigenous People would become infected during a stay in Paramaribo, and then would potentially spread the pox during expeditions, or upon returning to their villages away from the capital.

In the context of the spread of this infectious disease, it is of particular note that there is a general absence of Indigenous Peoples visiting the capital Paramaribo during the 'pox winter' of 1743-1744. Although the archival documents do not specify the ethnic identity of various Indigenous Peoples, who are simply referred to as "Indianen", nevertheless throughout his journals, the Governor of Suriname repeatedly mentions various bands of Free Indigenous Peoples ("troupen vrije Indianen") visiting Fort Zeelandia in Paramaribo - and who were well-received by the Governor. For instance, on Thursday May 16, 1743 - thus before the major pox outbreak during the winter of 1743-1744 - the Governor of Suriname wrote that several bands of Free Indigenous Peoples visited the Governor in Paramaribo this week; ${ }^{20}$ yet the next entry of bands of Free Indigenous Peoples arriving at the Fort in Paramaribo - and being well-received by the Governor - is almost a year later on Wednesday, April 22, 1744 - after the major pox outbreak during the winter of 1743-1744. ${ }^{21}$ Then, another month later - as if upholding a period of quarantine - other bands of Free Indigenous Peoples arrived in the capital, to be well-received by the Governor on May 15, 19, and 23; on June 7 and 8; and further on July 3 and 15. The last two bands thus arrived in Paramaribo at the same time the earlier discussed slave ship Maria en Elisabeth had moored there. ${ }^{22}$

One would have expected the bands of Free Indigenous Peoples to visit the capital sooner, for on December 24, 1743 - during the midst of the 'pox winter'- a ship had arrived in Paramaribo and within its cargo were several iron pots, several dozens of knives, scissors, mirrors, and 300 pounds of blue and white glass beads; ${ }^{23}$ all trade items very much sought after by Indigenous Peoples of Suriname. I therefore argue that this hiatus in visits of bands of the Free Indigenous Peoples to Paramaribo during the Summer, Fall, and Winter of $1743-1744$ is due to self-imposed social distancing measures by the Arawak- and/or Carib-speaking peoples, who must have been aware

\footnotetext{
${ }^{20}$ (Nationaal Archief, folio 175).

21 (Nationaal Archief, folio 462).

22 (Nationaal Archief, folio 518).

${ }^{23}$ (Nationaal Archief, folio 373, 374).
} 
eTropic 20.1 (2021) Special Issue: Pandemic, Plague, Pestilence and the Tropics

of the devastating epidemic of this highly contagious disease that had the capital Paramaribo, and the entire colony of Suriname, in its grip.

\section{Tuberculosis, Kuwamai, and Western Medicine (20th Century Accounts)}

On December 13, 1940, in the village of Senameini on the upper Jari River (see Figure 1) - two hundred years after the events in Paramaribo during the winter of 1743-44 and some five hundred kilometers south - Pajari told Lodewijk Schmidt that:

the 'coughing disease' [tuberculosis] is wiping out the Wayana people, and that in foreseeable time all Wayana will have disappeared. In the past, along both the rivers Jari and the Paru, there were numerous prosperous villages, each with a large population. Today only a few villages have remained with equally few inhabitants. This is all a result of the unfortunate 'coughing' disease. [...] Severely ill people, and those who were about to die, were placed in separate huts outside of the village (Duin, 2020, p. 69).

In addition, the Wayana told Lodewijk Schmidt - a Saramaka Maroon from the upper Suriname River - that "the medicines of the white man are excellent" and that "it is [the Ndjuka or Aucaner Maroons] who are bringing us the coughing disease that kills so many of our people, threatening to exterminate us" (Duin, 2020, p. 149). Schmidt, throughout his travels in Suriname, southern French Guiana and northern Brazil, provided a nuanced and touching description of the terrible effects of epidemic diseases such as tuberculosis - the 'coughing disease' - and influenza. Claudius de Goeje (1941, p. 95) remarked in a footnote that "[Morton C.] Kahn tested 70 Wayana of the Tapanahoni for tuberculosis, yet all tested negative" (translation and interpretation by the author). Oddly, in his investigation for tuberculin sensitivity among the Ndjuka or Aucaner Maroons of the Tapanahoni, of the 765 persons tested, only 18 or $2.3 \%$ gave a positive reaction (Kahn, 1936). Whatever the disease was that infected the Wayana - based on the demographic data collected by Schmidt, who counted a mere 338 individuals across Brazil, Suriname and French Guiana - we can conclude that 1940 was the demographic nadir for the Wayana Indigenous People (Duin, 2020, p. 149).

The Wayana way of life - as with other Amazonian Indigenous Peoples - is such that a contagious disease, once introduced, will spread quickly. As has been noted by Schmidt: "Among the Trio, as among the Wayana, all inhabitants from a single village, as well as the potential guests, eat from a single pot. Everyone dips his piece of cassava bread in the same pepper pot, which facilitates the spread of the disease" (Duin, 2020, p. 69). Moreover, they share a single drinking cup (calabash or ladle) 
eTropic 20.1 (2021) Special Issue: Pandemic, Plague, Pestilence and the Tropics

from which cassava beer - pooled in a single large vessel - is shared amongst all guests (Figure 3 ). The death of a village leader, death of many inhabitants of a single village, or simply the fear for this pandemic 'coughing disease', appeared to be the main reason for moving an entire village further inland, away from the main river systems that were the means of transportation for the Europeans and African diaspora communities.

Figure 3. Traditional social gathering among the Wayana

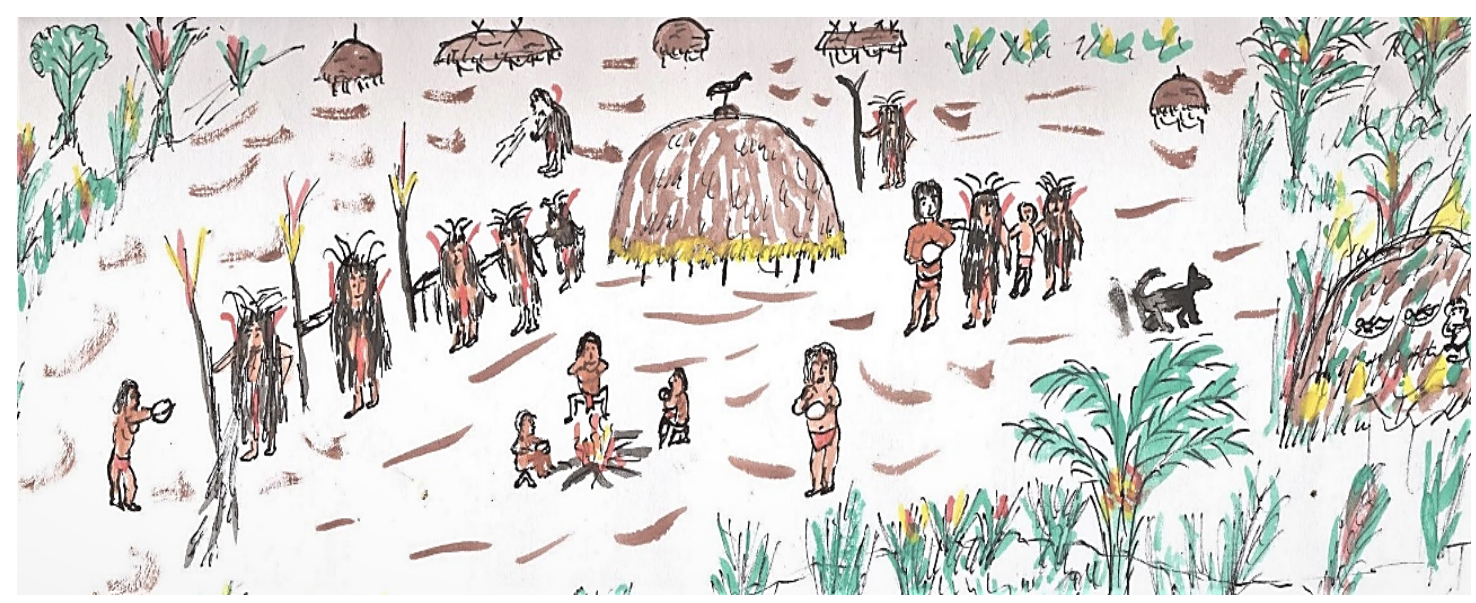

Watercolor painting by Ronnie Tikkaime, private collection of the author.

Wayana social memory recalls one specific incident in which many people died after such a social gathering in which lots of cassava beer was consumed. Kulijaman also mentions this incident in his description of epidemics (discussed in the previous section on Concepts of 'Illness'). The story goes:

«Pijai nai numëk, okï elï tïtëimëtohme okpatëla wayana ! " [...] Tïtëimëi jolok enokhe mane: mëlëme wayana, tïlëkhem pïnmetau, umelele ijume, wayana mëlëlëtau tïlomoi ijume (Chapuis \& Rivière, 2003, pp. 856-859).

"A piai (pïjai) had arrived. He drank some cassava beer (oki), yet left when nobody offered him any more cassava beer!" [as this is considered a serious insult in Wayana society] He left to send a malevolent entity (jolok): and it is therefore that the people (Wayana) died one after the other, many Wayana died all at once (tïlomoi) (ibid., translation and interpretation by the author).

This incident took place in the early to mid-twentieth century in the Upper Maroni Basin. After attending a large social gathering where hundreds of litres of cassava beer were distributed, many people who had attended the event began to die, and the 
eTropic 20.1 (2021) Special Issue: Pandemic, Plague, Pestilence and the Tropics

other Wayana began to reason that this great dying (tïlomoi) was the result of a malevolent entity (jolok) sent by a piai (pijai) who had attended the social gathering, but was not served any cassava beer. According to the surviving Wayana, the piai launched a revenge attack as a result of this grave insult.

In modern terminology such a social gathering would be labelled a "super spreader event". In November 2020, at the height of the COVID-19 pandemic, this incident, well known in Wayana social memory, was discussed in the context of recommended social distancing measures to prevent the spread of the coronavirus. The Wayana with whom I had this discussion concurred that there is a resemblance between COVID-19 and the great dying incident of oral history. However, the discussants were not willing to go on record, precisely because, as Wayana social memory proclaims, the great dying was the result of a revenge attack by a certain piai.

One of the Wayana Elders further stated that because several piai have been 'accused' of revenge attacks, or due to their inability to heal people from modern highly contagious diseases, their lives are in danger. Moreover, as the profession of the piai has become too dangerous, the youth no longer want to be initiated into training to become a piai - which is itself becoming a dying profession. Today, the Wayana prefer western medication for diseases that the piai cannot cure. This is not to say that the introduction of paracetamol and other western medicines has replaced the role of the piai; rather, the Western doctor (pinjou) and the piai function alongside each other in contemporary Wayana society.

\section{Voluntary Isolation as Extreme Survival Measure}

Traditionally, as a result of a great dying, Wayana leave a village where many people died - what we would consider the site of a super spreader event - and establish a new village at some distance from the village which they suspect houses a malevolent entity (jolok); the site now a place to avoid. This social distancing practice of moving away from the village and the river where a jolok had caused great death, was taken up as an extreme survival measure, I posit, by several ethnic communities - such as the Akuliyo, Wajarikulé, Saloema, and Pianogotto - of the Eastern Guiana Highlands.

Eighteenth century archival documents demonstrate that the "Pianocottos or Akouris" violently resisted the request from the then Governor of Suriname to have peace (study in progress by the author). Almost two hundred years later, Father Willem Ahlbrinck (1929) - a Dutch Missionary with a keen interest in the languages and cultures of the various original inhabitants of Suriname - aimed in vain to establish 'first contact' with the 'uncontacted' Saloema and Pianogotto. On February 22, 1942, Piké, the village leader of the eponymous village located near the sources of the Paru 
eTropic 20.1 (2021) Special Issue: Pandemic, Plague, Pestilence and the Tropics

de Este, stated to Lodewijk Schmidt how the Trio used to live in peace with the Saloema, yet at present all contact has ceased (Duin, 2020, p. 130). Within our current knowledge, it is most certainly the fear of contamination from deadly diseases - such as the aforementioned pox epidemic of 1743-44 and the twentieth century 'coughing disease' - that was the main reason for the Saloema, Pianogotto, Wajarikulé and Akuliyo to not (re)establish friendly relations with Indigenous and Maroon traders, and they retreated into 'voluntary isolation' as an extreme survival measure.

Elsewhere, I have proposed that Indigenous communities such as the Akuliyo, Wajarikulé, and other so-called "uncontacted peoples" residing in the triangle between the Tumuc-Humac Mountains and the rivers Tapanahoni and Alitani (see Figure 1), imposed upon themselves an extreme strategy of social distancing or 'voluntary isolation' (Duin, 2020, 76-79). Instead of being a relic from 'the Stone Age' - as these 'nomadic hunter/gatherer societies' have been repeatedly portrayed throughout the twentieth century - their social organisation and social distancing measures are a product of globalising history. This extreme survival measure of 'voluntary isolation' was instigated in order to protect themselves against the continent-wide spread of diseases such as measles, influenza, small pox and chicken pox, introduced by the Europeans. That these Indigenous communities went into self-isolation - adopted a 'nomadic' lifestyle and abandoned their agricultural practices - is evidence of a decisive measure to fight the existential threat of European coloniSation, rather than a measure of their natural condition of socio-political organisation.

\section{Demographic Decline (19th and early 20th Century Accounts)}

Every nineteenth and early twentieth century explorer in the Eastern Guiana Highlands witnessed entire village populations suffering from fever, running nose and headache resulting from highly contagious viral diseases; or the village had already been abandoned and they merely witnessed freshly dug graves (see Leprieur, 1834; de Bauve 1835; Crevaux, 1883; Coudreau, 1893; de Goeje, 1941, 1949; Duin, 2020 [Schmidt, 1942]). Although such historical documents are rare, they consistently document how many Indigenous People fell ill after each visit by a European, often accompanied by individuals with African roots, typically Ndjuka or Aucaner Maroons.

The population estimates for the Guianas demonstrate an extremely sharp demographic decline, to almost complete annihilation, in the mid-twentieth century (Hurault, 1963, 1972; Duin, 2020; for the case of the Wayana see Figure 4). We must take into account that the first population estimates for the Wayana Indigenous community as a whole - provided by Jules Crevaux (1883) - occurred more than one hundred years after the aforementioned devastating pox outbreak in Suriname in the winter of 1743-1744, an epidemic which most likely affected the Indigenous 
eTropic 20.1 (2021) Special Issue: Pandemic, Plague, Pestilence and the Tropics

communities in the inland uplands, and which moreover possibly also caused the Akouris (Akuriyo) to migrate further inland. Descriptions made by eighteenth century explorers hint towards more socio-politically complex Indigenous societies with higher population numbers, although they do not provide specific population estimates. These higher population numbers supporting a socio-political organisation with elements of regional integration prior to 1850 are suggested by the sharp demographic decline accounted for in the late nineteenth and early twentieth century (Figure 4).

Figure 4. Demographic decline of the Wayana population

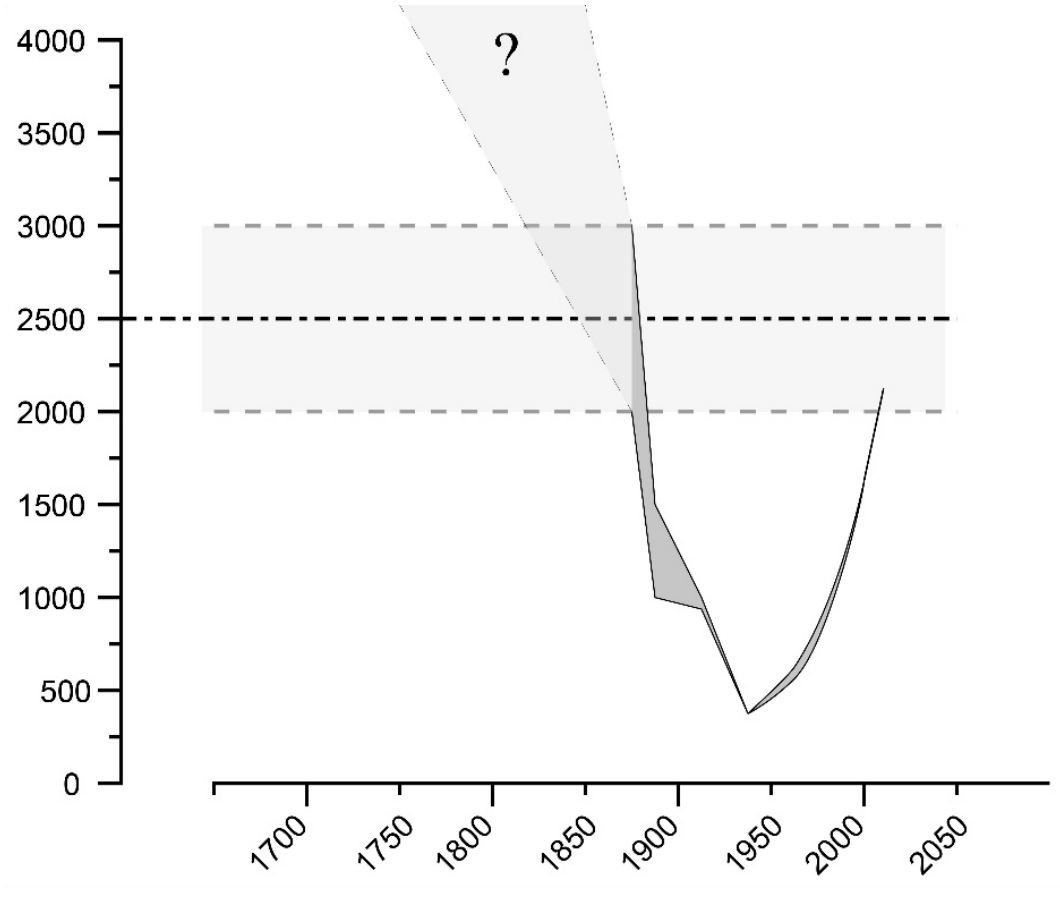

Source: compiled by the author.

During the eighteenth, nineteenth and early twentieth century, the surviving villagers self-isolated, moving away from the main rivers and becoming hostile towards Europeans and Africans as they feared a new outbreak of viral diseases for which their piai had no cure. In the aforementioned information on the 'coughing disease' gathered by the Maroon Lodewijk Schmidt in 1940-1942, he was told by the Wayana Pajari that there used to be large populations of Wayana along the rivers Jari and Paru (Brazilian Amapá), and that in foreseeable time they will all have disappeared due to the epidemic spread of viral diseases. Let me therefore briefly elaborate upon historical sources that may shed some light on what occurred along the rivers Jari and Paru prior to 1940. (See further elaboration in Duin, 2014).

On April 8, 1832, while exploring the Jari River, Adam de Bauve (1835) reported an outbreak of measles causing widespread death; including the sudden death of Hilario Feireire da Cruz, son of the colonel-governor of Macapá. According to de Bauve 
eTropic 20.1 (2021) Special Issue: Pandemic, Plague, Pestilence and the Tropics

(1835, p. 102), the Portuguese called this measles epidemic "charampa" (sarampo) and the French "rougeole" (see Duin, 2014, p. 746). Half a century later, in December 1888, Matawali reported to Henri Coudreau (1893, p. 369) that a smallpox outbreak above the sources of the Oyapock River had killed all inhabitants of a single village in just a few days. Coudreau stated that the informant Matawali was a Wayãpi man married to one of the last remaining members of the Tamokome community (see below). The decimated village, located on the left bank of the river Araguari, consisted of six houses, and, according to Coudreau must have fallen to the smallpox outbreak less than two years prior. He described in horrific detail the dreadful scene of "this village of the dead where neither ants, nor vultures, nor the winter rains, have been able to separate the skeletons of children from their mother's corpses" (1893, p. 370). (All translations from French, Spanish, German and Dutch are by the author).

In the comprehensive Ethnographic Survey of the Indians on the Divide of the Guianese and Amazonian River Systems, Peter Rivière stated that "the Tamocomes can be dealt with quickly," and he continued: "there are only four references to the tribe in the literature and the authors of two of those...never saw them.... The tribe is not significant and presumably disappeared" (1963, p. 189). This ethnographic survey was followed by ethno-historical studies conducted by Jean-Marcel Hurault (1972), Pierre Grenand (1972), and Dominique Tilkin-Gallois (1986), yet these studies mainly focused on the migration of the Wayãpi (Tupi-Guarani speakers) from the Xingu to the Oyapock River - in 1900 this river became the border between French Guiana and Brazilian Amapá - and their interactions with other nations in the area (see Duin, 2014, p. 745). The aforementioned horrifying detail of the demographic effects of epidemic death during the nineteenth century has not yet been foregrounded in these studies on the Tamocomes and the broader Eastern Guiana region, and thus the following short history, based on the author's previous work (see Duin, 2014, p., 745-746), sets the past within an epidemiological context.

Drawing on the expedition reports by François Leprieur (1834) and Adam de Bauve (1835) there is general consensus that the Tamocomes are a sub-group of the Wayãpi who in the early to mid-nineteenth century resided on the middle Jari region. The Tamocomes or "Tamokom (called Tamokũ by the Wayãpi)," according to Pierre Grenand (1972, p. 107) ${ }^{24}$ based on Coudreau (1893, p. 336), used to live in the south (i.e., south of the current Wayãpi settlements of the upper Oyapock) and were in contact with the Brazilians. In the 1850s, Grenand continued, the Tamokom with their leader Joachim Manuel, Yawalumiti (Yawarupixi), migrated to the Kouc [Cuc] where they intermarried with the Wayãpi. According to Dominique Tilkin-Gallois (1986, pp. 183-185), these Tomokomes or tamo-ko (Tamocomes or Tamokomes) are a subgroup of the Waiãpi-puku, the true Wayãpi. When Jules Crevaux (1883, p. 229) arrived

${ }^{24}$ All translations from French, Spanish, Dutch, German, Portuguese, and Wayana to English by the author. 
eTropic 20.1 (2021) Special Issue: Pandemic, Plague, Pestilence and the Tropics

at the creek Kouc [Cuc], on October 5, 1878, he realised that the Calayoua [kalaiwa] were not a distinct nation, but rather Oyampis [Wayãpi] who have close relations with Brazilians (Wayana today refer to non-indigenous Brazilians as kalaiwa). Grenand (1972, p. 118) proposed that these Calayoua [kalaiwa] met by Crevaux, were none other than the Tamokom [Tamocomes].

During the 1833 exploration of the source area of the Oyapock River, Leprieur (1834, p. 224) notes that the Tamocomes are a "tribe" of the nation of the Wayãpi residing along the Carapanatoube [Mapari] and Moucourou [Noucouru], tributaries of the river Jary [Jari], and follows this geographic placement with a short description of their physique and practices. A year earlier, on March 28, 1832, de Bauve (1835, pp. 9698) had visited the settlement of Oarapixi, the leader of the Tamocomes, which lies at the mouth of the Carapanatouba [Mapari] at the place where the river Topipocho [upper Jari] turns into the river Jary [middle Jari]. Oarapixi [Yawarupixi] was not born a Tamokome, de Bauve continued, but resided among them being invited by the Tamokome of the river Piraouër (a tributary of the Cuc) and he was later appointed "capitaine" after one of their chiefs had passed away. De Bauve specified that, about one month before his arrival, this leader of the Tamocomes had been baptised 'Joaquim Manoël' by a missionary who had reached this area. Furthermore, de Bauve already noted in 1832 an absence of traditional body painting in red and black with roucou and genipa respectively, and an influence of European hairstyle and dress (1835, pp. 100-101).

Several decades later, in October 1889 , Coudreau $(1893$, p. 331,336$)$ arrived in the village of Ouira in the Upper Cuc Basin. Ouira, the village leader, was thought to be fifty years old, providing an estimated year of birth at 1839 - about seven years after the aforementioned expedition by de Bauve. Moreover, Coudreau continued, Ouira's father is Yaouaroupicic who goes by his Christian name "Joaquim-Manoel". Yaouaroupicic [Yawarupixi] is the very same person as Oarapixi or the Joaquim Manoël mentioned by de Bauve (1835, p. 97). According to Coudreau (1893, p. 336), when Yaouaroupicic travelled with his son Ouira along the banks of the Grand-River - the Amazon - Ouira received the Christian name of Joaquim.

Capitan Yaouaroupicic [Yawarupixi], Coudreau (1893, p. 336) continued, was a great leader who led the Wayãpi and Tamokome in one of their last migrations from the Amazon to the north. Coudreau stated that Yaouaroupicic was raised by the Brazilians of the Amazon, and that he spoke very well their language, i.e., Brazilian Portuguese. This resonates with Crevaux's (1883, p. 229) statements regarding the Calayoua [kalaiwa] of the Cuc. Beyond the fundamental ethnohistoric facts for geo-positioning Indigenous Peoples, these primary sources contain critical information for contextualising the historical process. 
eTropic 20.1 (2021) Special Issue: Pandemic, Plague, Pestilence and the Tropics

Rather than an auto-denomination of a nation, tamokome thus appears to be a term of reference for a certain indigenous community who had strong ties with the nonindigenous Brazilians. That Tamocome (or Tamokome) is a mere term of reference, is indicated by the suffix -me (de Goeje 1946, pp. 125-126) which indicates that the informant was aware that these people are not the 'true' Tamok; but rather, only like Tamok (Tamok\{o\} me). This leaves us with the question, who, or what, are the 'true' Tamok(o)? And why was this Wayãpi sub-group from the middle Jari, whose leaders were raised by the non-indigenous Brazilians and who spoke Brazilian Portuguese, named after Tamok?

\section{Wayana Oral History: Jolok Tamok and Wayana Tamok ukuknanom ${ }^{25}$}

In 2000, while conducting fieldwork on Wayana socio-political organisation (Duin, 2009,2012 ), a local pijai (piai) stopped by and asked me if he could see my folder with drawings (including copies of late nineteenth century engravings). When he saw Edouard Riou's engraving of the dance of the pono (Crevaux, 1883, p. 259), ${ }^{26}$ he expressed in a loud voice "Tamok"! Claudius de Goeje (1941, pp. 111-113), in his brief cross-cultural analysis of the whip-dance, was the first to associate the name Tamok to the pono-dance described by Crevaux (1883:258). The social and cultural patterns and attitudes that gave rise to this ritual whip dance (pono), as well as the complexity of the related materiality, particularly the full body Tamok mask, have been discussed in detail elsewhere (Duin, 2014, 2021). What is important here, is how this ritual dance relates to Wayana concepts of illness and health - and especially viral epidemics.

In short, the whip-dance witnessed by Jules Crevaux on October 28, 1878, on the Upper Paru de Este and a decade later by Henri Coudreau (1893, pp. 174-185), according to a Wayana oral history recorded in 2003, were Wayana - specifically Upului, one of the core subgroups of the Wayana confederation - dancing in imitation of Tamok in order to mock the widespread death brought by the Malevolent Entity Jolok Tamok (Duin, 2009, pp. 517-526; 2012). This whip-dance is par excellence a "mode of consciousness of the social present, expressed in terms of the relation of that present to its past (and future)" (Turner, 1988, p. 279). The Malevolent Entity Jolok Tamok is at the same time beautiful and dangerous.

The Wayana|Upului dancing in imitation of Tamok did not have the original weapon of Tamok. The weapon of the Malevolent Entity Jolok Tamok brought epidemic death,

\footnotetext{
${ }^{25}$ This section and the next on the Return of the Malevolent Entity are succinct versions of the author's more elaborate study on the Tamok whip-dance (Duin, 2009, pp. 517-526; Duin, 2014, p.746-755), but in this case seen in the new light of viral epidemia.

${ }^{26}$ In his Vocabulary, Jules Crevaux (1882, p. 9) erroneously stated that pono is the name of the whip, whereas Henri Coudreau (1892, p. 25) corrected that the whip used during the pono-dance is named taï.
} 
eTropic 20.1 (2021) Special Issue: Pandemic, Plague, Pestilence and the Tropics

yet no person died during the performance of the whip-dance. The weapon of Tamok, is called itain or Tamok tain. Its root tai is also the root of taitikai (thundering; literally: 'it does tai' with the onomatopoeia 'tai'). The Malevolent Entity Jolok Tamok, according to Wayana social memory, were carrying a 'thundering whip' causing 'thunder strikes' so powerful that they brought down trees as when clearing a farm plot, breaking the top of a big tree, and shattering houses into pieces, thereby destroying them and causing them to collapse (Duin, 2009: Table C-15, lines 10-23). These thundering sounds and their deadly effects - bringing down trees and houses - were so frightening that the inhabitants abandoned their village never to return to the site where this dreadful encounter took place. Elsewhere I have argued that this 'thundering whip' was a harquebus carried by the members of the Spanish foot patrol of July 1542 (Duin, 2009, 2014, 2021). The Malevolent Entity was European, and lethal - even after leaving.

Figure 5. The beautiful yet dangerous Malevolent Entity Jolok Tamok

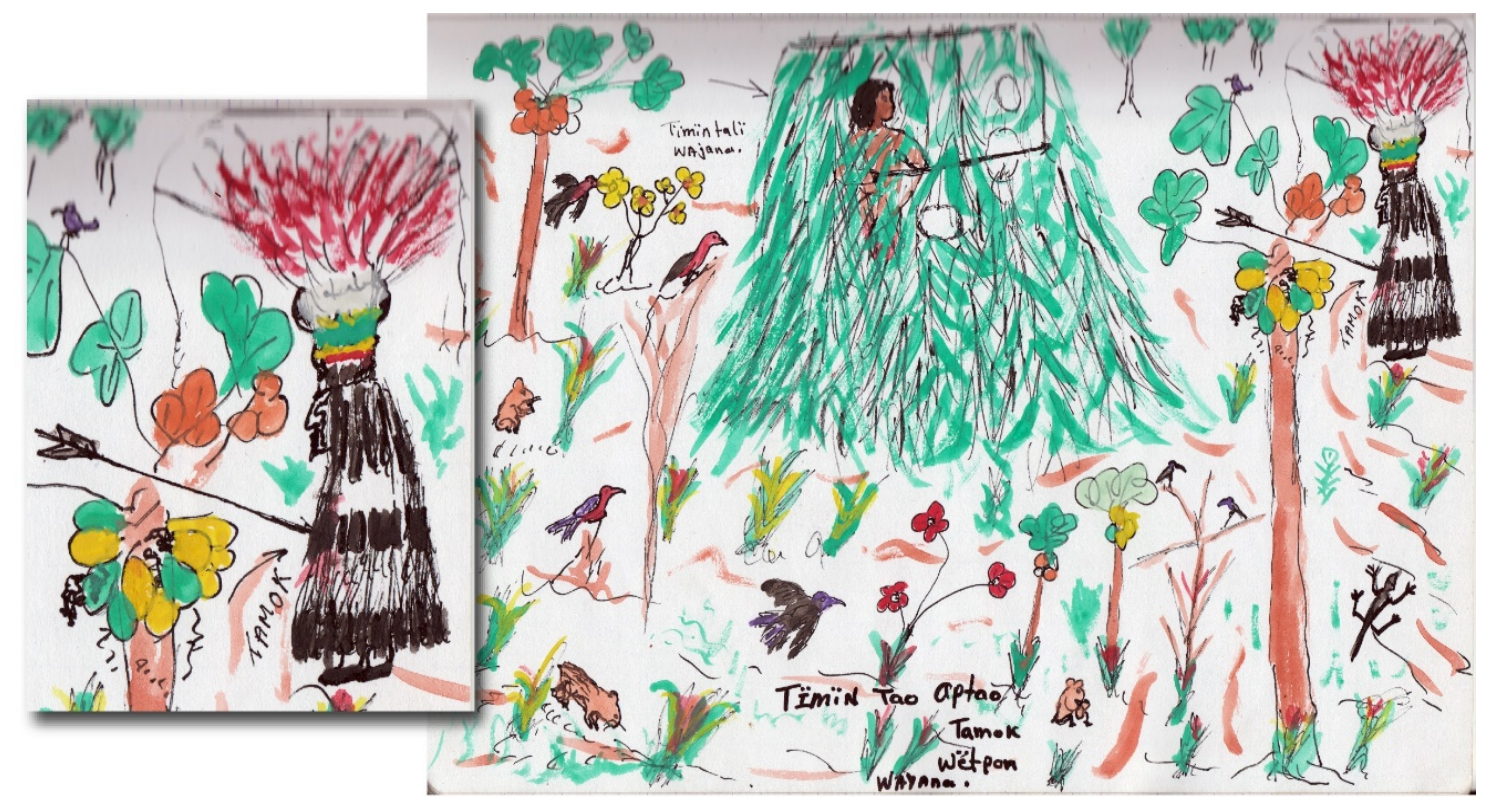

Watercolor painting by Ronnie Tïkaime; private collection of the author.

Significantly, after the 'thundering whip' and the Malevolent Entities had left the village the inhabitants were struck by an epidemic of fever and headaches, and children and pregnant woman died (Duin, 2009: Table C-15: lines 29-30). This is why Kulienpë emphasised that the Malevolent Entity Jolok Tamok was "without a master, they were of their own creation" (Duin, 2009, line 27). Not even the powerful jolok-pijai was able to contain the epidemic causing fever and death (Duin, 2009, line 31). The narrator, before concluding this narrative of the Jolok Tamok (Duin, 2009, line 28, 33), stated that after this event the people no longer intended to reside in this village where so many people had died and they left, never return to this river. 
eTropic 20.1 (2021) Special Issue: Pandemic, Plague, Pestilence and the Tropics

In the words of Kulienpë, recorded in the village Alawateimë enï, on January 10, 2003:

\begin{tabular}{|c|c|}
\hline ai molo a & $\begin{array}{l}\text { They abandoned this village } \\
\text { went downstream. That was it. }\end{array}$ \\
\hline $\begin{array}{l}\text { Moloinë tïlëkhemïhpe tot tëtïhe; } \\
\text { ijasitutpïkom, ijasitutpïkom } \\
\text { mëwihnë; tïlëkhem pëlëmnë, } \\
\text { jemnë, uputpë. }\end{array}$ & $\begin{array}{l}\text { Later they were struck by epidemics; } \\
\text { heat, very hot temperatures; the } \\
\text { epidemics of being very tired, of } \\
\text { fever, of headache. }\end{array}$ \\
\hline Tikai Tamok ijasitumhakan. & Doings by the Tamok's painful heat. \\
\hline $\begin{array}{l}\text { Malalë tïlëkhem, malalë } \\
\text { ijasitunkomke tillëmëphe } \\
\text { muletom talan, wëlïham wamela } \\
\text { hapon tëweihamo tïlëmëphe. }\end{array}$ & $\begin{array}{l}\text { Thus were the epidemics, so through } \\
\text { the fever children could die, the } \\
\text { women who were a little sick [= } \\
\text { pregnant] would die. }\end{array}$ \\
\hline$[\ldots]$ & {$[\ldots]$} \\
\hline $\begin{array}{l}\text { Masike elamhak Waijana } \\
\text { tëwëtïhe. Sija umëkïhela } \\
\text { tëwëtïhe; helëkwak umëkïhela. }\end{array}$ & $\begin{array}{l}\text { This is how the Wayana got } \\
\text { frightened. They never returned } \\
\text { here; they never would return to this }\end{array}$ \\
\hline
\end{tabular}

Translated from Wayana to French by Takwali Kulisa; translated from French to English by the author (Duin, 2009, p. 521).

\section{Social Present: Return of the Malevolent Entity}

It is said that after Tamok left, the Wayana|Upului were struck with fever and headaches, and many children and pregnant woman died. After this terrific and terrifying event of first encounter - with the 'thundering whip', the Malevolent Entity Jolok Tamok, outbreak of fever and death - the people abandoned the village. If my interpretation is correct, this is the first eye-witness account of an epidemic viral disease in Amazonia that has remained in Wayana social memory for over five hundred years. With the ongoing COVID-19 pandemic, Westerners may finally gain some empathy for the indigenous response of social distancing and the fear of outsiders who may potentially bring new waves of deadly viral diseases.

Kulienpë in his reflective conclusion to the oral history of the Malevolent Entity Jolok Tamok stated that "this is what Tamok did, the [uncontrollable] [Malevolent Entity] without master. The latter Tamok were numerous, are very powerful, powerful indeed, and incomparable with the [Malevolent Entities] that we know" (Duin, 2009, table C15, lines 31-32). Other Malevolent Entities (jolok) have a Master (jum) via whom the pijai can control the caused sickness [compare with the concept of "Mothers" among 
eTropic 20.1 (2021) Special Issue: Pandemic, Plague, Pestilence and the Tropics

the Yagua in Nord-East Peru (Chaumeil, 1983)]. Since the Tamok have no Master they are of their own creation - and because they have the Power, they are very strong jolok (Malevolent Entity). I argue that it is this uncontrollable viral disease that is the condition in which Tamok functions and that epidemic death is the real condition of its genesis; rather than the mourning of the death of an individual chief as suggested by Crevaux (1883, p. 258) and repeated without critical assessment by earlier (Roth, 1924, p. 665; Gillin, 1948, p. 852; Hemming, 1978, p. 194), and more recent scholars of Amazonia.

As discussed in more detail elsewhere (Duin, 2014), rather than being a mortuary ceremony, the Wayana|Upului were mocking epidemic death itself by means of a ritualised whip-dance (pono). When Crevaux and Coudreau recorded this whip-dance during the nineteenth century it was in full process of development, while simultaneously drawing on ancient Amazonian traditions and histories. The weapon of Tamok was the thundering whip, which was "alakapuha katïp" (literally: "[sounding] like a gun[shot]"). ${ }^{27}$ Yet more powerful than it's 'thunder strikes' was the viral disease and mortality rate resulting from the first encounter with the Malevolent Entity Tamok.

Regarding the whip-dance event, it is vital to notice that although the Tamok dancers are strangers and potentially dangerous social others, they aid in the construction of the community roundhouse (tukusipan) and bring the gift of basketry and other small wooden utensils essential in the production of cassava beer - the life elixir and social lubricant of Amazonian societies. Then again, the communal sharing of cassava beer with people from other communities enabled the infinite spread of viral diseases over vast geographic spaces.

The historical situatedness of the Tamok whip-dance calls for for a multi-dimensional analysis with the aim to gain insight into an indigenous approach to historical consciousness in Guiana. The nineteenth century Tamok whip-dance was an authentic and active historical process to engage with the social present because many Wayana were dying from a viral disease locally known as kuwamai. And this dance was active some forty-five years prior to the expeditions by Crevaux and Coudreau, de Bauve (1835, p. 102), and the reported measles outbreak on the Jari. No wonder the Indigenous People of the Jari must have thought ... "the Malevolent Entity Jolok Tamok has returned!!!"

\footnotetext{
${ }^{27}$ The Wayana name alakapuha is derived from harquebus (arcabusa in Spanish), with the typical interchange of the alveolar liquid/flap r/l; c/k; b/p; and s/h.
} 
eTropic 20.1 (2021) Special Issue: Pandemic, Plague, Pestilence and the Tropics

\section{Epilogue}

After submitting this manuscript, some events took place among the Wayana that need mentioning in this context, even though they are yet to be studied in further detail to be fully understood.

Indifferent towards the COVID-19 measures translated into the respective indigenous languages, and disregarding the large number of Wayana that fell sick in the spring of 2020 due to the coronavirus, Wayana only wear a facial mask when visiting the main administrative centres in Maripasoula, Saint-Laurent du Maroni, and in the capitals Cayenne and Paramaribo. They do not uphold social distancing measures when in the village or when traveling by canoe.

Wayana attribute illness, in particular vast spreading viral diseases due to pathogenic microbes, to the intervention of a malevolent entity (jolok). Because of the indigenous etiology relating illness to the intervention of a malevolent entity (jolok), in conjunction with the fact that the traditional piai is not effective against viral diseases introduced by Europeans and Afro-Surinamese, many indigenous people now turn to the Church.

It is surrealistic to witness a potential super spreader event which lasted three full days and was attended by hundreds of Wayana from across Suriname and French Guiana during the time of an increased enforcement of social distancing and other coronavirus measures worldwide. This is not the place to explore in depth the phenomenon of Christian conversion in Amazonia (Pollock, 1993; Albert \& Ramos, 2000) and potential parallels with the Hallelujah-movement in Guyana (Butt Colson, 1994-1996). Since the turn of the twenty-first century, the Baptists Protestant Church supported by American evangelicals is gaining strength among the Wayana in Suriname and French Guiana. This phenomenon of Christian conversion is by and large situated within the general belief that Jeisu Këleisuh (Jesus Christ) offers a protective cloak (soldati upo) to protect against seitënuh (satan) - the malevolent entity (jolok). The belief in Christ offers a protection against illnesses brought by Europeans that the traditional piai cannot offer. 
eTropic 20.1 (2021) Special Issue: Pandemic, Plague, Pestilence and the Tropics

\section{References}

Ahlbrinck, W. (1931). Encyclopaedie der Karaïben beheizend taal, zeden en gewoonten dezer Indianen. (Verhandelingen der Koninklijke Akademie van Wetenschappen te Amsterdam: Afdeeling Letterkunde: Nieuwe Reeks: Deel, XXVII). De Koninklijke Akademie van Wetenschappen te Amsterdam.

Ahlbrinck, W. (1929). Vijf maanden in het Oerwoud. De Bont \& Zoon.

Albert, B. \& Ramos, A. (Eds.). (2000). Pacificando o branco. Cosmologias do contato no Norte-Amazônico. UNESP.

Butt Colson, A.J. (1994-1996). 'God's Folk'. The evangelization of Indians in Western Guiana and the Enthusiastic Movement of 1756. Antropológica, 86, 3-111.

Camargo, E. \& Tapinkili (2010). Hakëne omijau eitop: Wajana-Palasisi; Dictionnaire bilingue Wayana-Français. CELIA/DRAC-Guyane/Tekuremai.

Chapuis J. \& Rivière H. (2003). Wayana eitoponpë: une histoire orale des Indiens Wayana. Ibis Rouge.

Chapuis J. (2015). La perspective du mal: des dérèglements du corps à l'ordre du monde chez les Wayana de Guyane. Ibis Rouge.

Chaumeil, J-P. (1983). Voir, savoir, pouvoir: le chamanisme chez les Yagua du nord-est péruvien. Editions de l'EHESS.

Coudreau, H. (1892). Vocabulaires methodiques des langues Ouayana, Aparaï, Oyampi, Emérillon. Maisonneuve.

Coudreau, H. (1893). Chez nos indiens: quatre années dans la Guyane française (18871891). Hachette.

Crevaux, J. (1882). Grammaires et Vocabulaires Roucouyenne, Arrouague, Piapoco et d'autres langues de la région des Guyanas. Bibl. Ling. Améric., no. 8.

Crevaux, J. (1883). Voyages dans l'Amérique du Sud. Hachette.

de Bauve, A. (1835). Voyage dans l'intérieur de la Guyane Centrale de septembre 1831 à juin 1832. Bulletin de la Société de Géographie, 7, 21-41, 81-109.

de Goeje, C.H. (1941). De Oayana-Indianen. Bijdragen tot de taal-, land-en volkenkunde van Nederlandsch-Indië, 100 (1), 71-125. https://doi.org/10.1163/2213437990001269

de Goeje, C.H. (1942). De Inwijding tot Medicijnman bij de Arawakken (Guyana) in Tekst en Mythe. Bijdragen tot de taal-, land- en volkenkunde van Nederlandsch-Indië, 101 (1), 211-276. https://doi.org/10.1163/22134379-90001253

de Goeje, C.H. (1943). Philosophy, Initiation and Myths of The Indians of Guiana and Adjacent Countries. Archivers Internationales d'Ethnographie, (44), 1-136.

de Goeje, C.H. (1946). Études linguistiques Caraïbes (Tome II)." Verhandelingen der koninklijke Nederlandsche akademie van wetenschappen, afdeling Letterkunde 49, no 2. North-Holland Publishing Company.

de Goeje, C.H. (1949). The physical world, the world of magic, and the moral world of Guiana Indians. Unpublished manuscript for the twenty-nineth International Congress of Americanists.

Duin, R.S. (2009). Wayana Socio-Political Landscapes: Multi-Scalar Regionality and Temporality in Guiana. [Doctoral dissertation, University of Florida]. ProQuest Dissertations Publishing. https://ufdc.ufl.edu/UFE0041100/00001

Duin, R.S. (2012). Ritual Economy: Dynamic Multi-Scalar Processes of Socio-Political Landscapes in the Eastern Guiana Highlands. Antropológica, 56 (117-118), 127-174.

Duin, R.S. (2014). Historical complexity of myth: in search of the genesis of the whip-dance whereby Wayana dance in imitation of Tamok (Eastern Guiana Highlands). Boletim Museo Paraense Emílio Goeldi. Ciences Humanes, 9 (3), 741-772.

https://doi.org/10.1590/1981-81222014000300013 
eTropic 20.1 (2021) Special Issue: Pandemic, Plague, Pestilence and the Tropics

Duin, R.S. (2020). The Humble Ethnographer: Lodewijk Schmidt's Accounts from Three Voyages in Amazonian Guiana. Brill.

Duin, R.S. (2021). Tamok and the Tamocomes: Ethno-Historical Accounts on Epidemics and Resilience in the Eastern Guiana Highlands (Amazonia). Ethnohistory, (in review).

Fausto, C, \& Heckenberger, M.J. (2007). Introduction. Indigenous History and the History of the 'Indians.'. In M.J. Heckenberger, \& C. Fausto (Eds.), Time and memory in indigenous Amazonia: anthropological perspectives (chapter pages pp. 1-15). University Press of Florida.

Gillin, J. (1936). The Barama River Caribs of British Guiana (Papers of the Peabody Museum of Archaeology and Ethnology, Harvard University, 14,2). Peabody Museum of American archaeology and ethnology.

Gillin, J. (1948). Tribes of the Guianas and the Left Amazon Tributaries. In J. Steward (Ed.), Handbook of South American Indians, volume 3. Tropical Forest Tribes (chapter pages pp. 799-860). Smithsonian Institution, Bureau of American Ethnology, Bulletin 143.

Grenand, P. (1972). Les relations intertribales en Haute Guyane, du XVIIle siècle à nos jours. [MA-thesis, Paris V]. Institut d'ethnologie.

Harris, A. (1928). A Relation of a Voyage to Guiana by Robert Harcourt 1613. Hakluyt Society.

Hemming, J. (1978). Red Gold: The Conquest of the Brazilian Indians, 1500-1760. Harvard University Press.

Hill, J. (2009). History, Power, and Identity: Amazonian Perspectives. Studia Anthropologica, $3,25-47$.

Hurault, J. (1963). Les Indiens de Guyane Française: problèmes pratiques d'administration et de contacts de civilisation. Nieuwe West-Indische Gids, 42 (2), 81-186.

Hurault, J. (1972). Français et Indiens en Guyane 1604-1972. Union Générale d'éditions.

Janssens, U. (1981). Matthieu Maty and the Adoption of Inoculation for Smallpox in Holland. Bulletin of the History of Medicine, 55 (2), 246-256.

Kahn, M.C. (1936). A tuberculin survey of the upper Aucaner Bush Negroes in Dutch Guiana. American Journal of Hygiene (American Journal of Epidemiology), 24 (3), 456-478. https://doi.org/10.1093/oxfordjournals.aje.a118279

Leprieur, F. (1834). Voyage dans la Guyane Centrale. Bulletin de la Société de Géographie, $1,201-229$.

Penard, A.Ph. (1928). Het Pujai-geheim der Surinaamse Caraiben. Bijdragen tot de taal-, land- en volkenkunde van Nederlandsch-Indië, 84 (1), 625-671.

Pollock, D. (1993). Conversion and "community" in Amazonia. In R. Hefner (Eds.), Conversion to Christianity: historical and anthropological perspectives on a great transformation (chapter pages pp. 165-197). University of California Press.

Rivière, P. (1963). Ethnographic Survey of the Indians on the Divide of the Guianese and Amazonian River Systems. [BA-thesis, Oxford University].

Roth, W. (1915). An Inquiry into the Animism and Flok-lore of the Guiana Indians. Thirteenth Annual Report of the Bureau of American Ethnology to the Secretary of the Smithsonian Institution, 1908-1909, 103-386. U.S. Government Printing Office.

Roth, W. (1924). An Introductory Study of the Arts, Crafts, and Customs of the Guiana Indians. Thirty-Eighth Annual Report of the Bureau of American Ethnology to the Secretary of the Smithsonian Institution, 1916-1917, 25-720. U.S. Government Printing Office.

Staden, H. (2008). Hans Staden's True History: an account of cannibal captivity in Brazil. Edited and Translated by Neil Whitehead and Michael Harbsmeier. Duke University Press. https://doi.org/10.1215/9780822389293 
eTropic 20.1 (2021) Special Issue: Pandemic, Plague, Pestilence and the Tropics

Tilkin-Gallois, D. (1986). Migração, Guerra e Comércio: os Waiapi na Guiana. FFLCH-USP. [Originally presented in 1980 as a Master thesis, USP].

Tilkin-Gallois, D. (Ed.). (2005). Redes de relações nas Guianas. NHII-USP.

Turner, T. (1988). Ethno-Ethnohistory: Myth and History in Native South American Representations of Contact with Western Society. In J. Hill (Ed.), Rethinking History and Myth. Indigenous South American Perspectives on the Past (chapter pages pp. 235-281). University of Illinois Press.

van Coll C. (1903). Gegevens over land en volk van Suriname. Bijdragen tot de taal-, landen volkenkunde van Nederlandsch-Indië, 55 (1), 451-650. https://doi.org/10.1163/22134379-90002044

van Panhuys, L.C. (1936). Opvattingen van Zuid-Amerikaansche Indianen nopens ziekten en geneeswijzen. Nieuwe West-Indische Gids, 17 (1), 51-57.

https://doi.org/10.1163/22134360-90000869

Whitehead, N.L. (2003). Introduction. In N.L. Whitehead (Ed.), Histories and Historicities in Amazonia (chapter pages pp. vii-xx). University of Nebraska Press.

Whitehead, N.L. \& Wright, R.M. (2004). In Darkness and Secrecy: The Anthropology of Assault Sorcery and Witchcraft in Amazonia. Duke University Press. https://doi.org/10.1215/9780822385837

\section{Acknowledgements}

This article would not have been possible without the numerous discussions I had over the years with several Wayana Elders. In particular I would like to thank Kilian Toineike for his general knowledge of Wayana heritage; Takwali Kulisa for his discussions on Wayana language and the translations of the Wayana texts; Kulienpë for his stories of Jolok Tamok and Wayana Tamok ukuknanom; Tënepo for his knowledge of the pijai; Ronnie Tikaime for his wonderful watercolor drawings which illustrate this article; and many more Wayana who remain unnamed here. I thank the anonymous reviewers for their feedback to improve my manuscript - and specifically the suggestion to change the term "Evil Spirit" into "Malevolent Entity". And last, but not least, Anita Lundberg for her wonderful copy editing of my manuscript. Nevertheless, the content and all interpretations made in this article remain the sole responsibility of the author.

Dr Renzo S. Duin obtained a PhD in Anthropology from the University of Florida, USA. His dissertation focusses on the socio-political landscapes in the Eastern Guiana Highlands, northern Amazonia. His research and publications cover a broad range of topics from material culture, intangible heritage, social memory, oral history, identity, historical ecology, decolonisation, and the intertwining nature of these topics. He has held research and teaching positions at the University of Florida, USA, and Leiden University, the Netherlands, and research positions at Oxford University and University College London, UK. In this capacity he led and participated in various international and interdisciplinary research projects. He is founder and board member of the International Center for Amazonian Indigenous Knowledge (AMIK) www.amiknow.org. 